\title{
Victor Gollancz: um editor socialista nos anos do Popular Front britânico*
}

\author{
Matheus Cardoso da Silva**
}

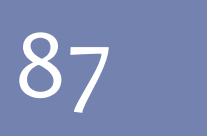

Resumo: O artigo trata da trajetória de Victor Gollancz (1893-1967), um dos mais importantes editores e ativistas humanitários britânicos do século XX. Como livreiro, Gollancz fundou sua própria editora em 1927, a Victor Gollancz Ltd., uma das mais bem sucedidas de seu tempo. Em 1935, seria cofundador do Left Book Club em Londres, considerado o primeiro clube do livro da era moderna na Grã-Bretanha, cujos trabalhos duraram até 1947 e inspirou a criação de mais de 1.500 seções locais por toda a Inglaterra e mais de 15 outras seções internacionais, com filiais em todos os continentes. Como militante humanitário, Gollancz foi responsável por inúmeras campanhas de apoio aos refugiados da Guerra Civil Espanhola na Inglaterra e, durante a Segunda Guerra Mundial, das vítimas civis na Alemanha. Fatores que o tornam figura-chave no Popular Front britânico.

Palavras-chave: Victor Gollancz; história do livro; esquerda britânica.

\begin{abstract}
This article aims to consider the paths of Victor Gollancz (1893-1967), one of the most important publishers and British humanitarian activists of the Twentieth century. As a bookseller, Gollancz founded his own company in 1927, Victor Gollancz Ltd., one of the most successful of his time. In 1935, he co-founder the Left Book Club in London, considered the first book club of the modern era in Britain, whose work lasted until 1947 and inspired the creation of more than 1,500 local branches throughout England and more than 15 other international sections with branches on every continent. As a humanitarian activist, Gollancz was responsible for numerous campaigns to support refugees from the Spanish Civil War in England and during the Second World War, the civilian victims in Germany. Factors which turns him a key-figure on the British Popular Front.
\end{abstract}

Keywords: Victor Gollancz; history of the book; british left.

* Este artigo apresenta parte dos resultados da pesquisa que desenvolvi durante o período de estágio doutoral realizado na Royal Holloway, University of London, sob supervisão do Prof. Dr. Gregory Claeys, no primeiro semestre de 2015, para a tese intitulada, "As cartas de Londres: George Orwell nas redes intelectuais entre Londres e Nova York, 1941-1946”, defendida em 2016, no DH-USP, e para a qual contei com bolsa PDSE da CAPES.

** Doutor em História Social pelo Departamento de História da Universidade de São Paulo. Pesquisador do GRUPHI - Grupo de Pesquisa em História Intelectual e do LabTeo - Laboratório de Teoria da História e História da Historiografia, ambos do Departamento de História, Universidade de São Paulo. Endereço profissional: Avenida Professor Lineu Prestes Butantã - CEP 05508900 - São Paulo, SP - Brasil. Telefone: (11) 30913786. E-mail: stardus_mat@yahoo.com.br. 


\section{Introdução}

Nascido em Londres, em 9 de abril de 1893, e falecido também em Londres, em 8 de fevereiro de 1967, Victor Gollancz ${ }^{1}$ era filho de emigrados judeus, originários da Alemanha e da Polônia. Foi educado em Oxford e se tornou professor primário na década de 1910. Já no final da Primeira Guerra Mundial, em 1917, Benjamim Seebohm Rowntree, sociólogo britânico, responsável por pesquisas sobre a pobreza em centros urbanos ingleses como York e autor de inúmeros artigos e livros sobre as condições sociais de famílias pobres na Inglaterra, ${ }^{2}$ recrutou Gollancz para integrar o Reconstruction Committee, organização ligada ao Partido Liberal, formada para planejar a reconstrução britânica depois da Primeira Guerra Mundial. Trabalhando para o comitê, Gollancz se aproximou de William Wedgwood Benn, deputado pelo Partido Liberal, junto do qual trabalhou como secretário do Radical Research Group.

Benn foi o responsável por apresentar Gollancz a seu irmão, Ernest Benn, diretor da Benn Brothers, editora londrina que publicava revistas e pequenos romances. Na Benn Brothers, Gollancz iniciaria sua trajetória como livreiro, atuando primeiro como agente literário, buscando contribuidores para a editora. Mais tarde, depois de uma divisão interna, a Benn Brothers se divide, permitindo a Ernest Benn fundar sua própria companhia. Já como empregado da Ernest Benn Ltd., Gollancz publicou uma série de livros de arte que ganharam boa repercussão, antes de dedicar atenção para a publicação de romances e livros de poesia. A partir de então, Gollancz conseguiu atrair para a editora romancistas importantes do panteão literário britânico das primeiras décadas do século XX, entre eles Edith Nesbit, Robert W. Service e, o mais famoso de todos, H. G. Wells. Devido ao crescimento da figura de Gollancz dentro da Ernest Benn Ltd., seu proprietário viu seu poder gradualmente diminuído. Somado a isso, aumentaram as desavenças políticas entre ambos, com Benn assumindo suas posições conservadoras, enquanto Gollancz já defendia abertamente posições de esquerda. O que levou à sua demissão no final de outubro de 1927.

Gollancz fundaria sua própria companhia ainda no mesmo ano 1927, a Victor Gollancz Ltd. Por meio dela, Gollancz pôde, por fim, conciliar sua militância política e a atuação como livreiro, que, já na década de 1930, o transformaria em um dos mais importantes editores britânicos do século XX. Militância que favoreceria a fundação do Left Book Club, na cidade de Londres, em plena depressão e reorganização da esquerda britânica dentro do Popular Front, em 1935.

Ao longo de sua vida, Gollancz conciliou sua atividade como editor com uma árdua militância humanitária, incluindo o pacifismo, a abolição da pena capital, a situação da população civil na Espanha durante a Guerra Civil Espanhola (1936-39) e na Alemanha durante a Segunda Guerra Mundial, etc. Como grande parte da esquerda britânica, manteve ainda fortes laços com membros do National Indian Congress e o movimento de independência indiano, tanto quanto os movimentos de independência em outras colônias britânicas, pelas quais acabou empenhando também o Left Book Club.

E justamente o Left Book Club foi seu maior empreendimento, apesar de ter (1913), além dos livros The Human Needs of Labour (1918) e The Human Factor in Bussiness (1921). 
funcionado por apenas doze anos. Neste período, o LBC criou mais de 1.500 seções espalhadas por diversas cidades da Inglaterra. Em 1938, no ápice de seu funcionamento, o clube contava com 57 mil membros associados, cifras consideráveis para a época, sendo reconhecido como a maior organização política da Grã-Bretanha no período. O LBC motivou ainda a criação de 15 grupos ao redor do globo, com ligações em todos os continentes. Além da possibilidade da circulação das edições produzidas pelo LBC e da publicação oficial do clube, a revista Left News, essas redes criaram um grande circuito com a finalidade de difusão dos debates da esquerda e a promoção do socialismo. Ao mesmo tempo, tais redes conectaram lutas e causas nacionais em uma rede internacional de circulação de ideias. Caminho propício para dar notícia aos europeus sobre diversas causas fora da Europa, como os nacionalismos locais e a luta anticolonial nas periferias do império britânico. Com isso, é possível afirmar, Gollancz se estabeleceu como uma das figuras mais interessantes dentro do Popular Front britânico, cujo dinamismo representou ao mesmo tempo o calor daqueles anos e suas contradições.

\section{A Victor Gollancz Ltd.: a história de uma editora revolucionária}

Ao longo de sua vida, Victor Gollancz se via primeiramente como um educador e reformista. Logo depois de deixar Oxford, Gollancz trabalhou junto a Seebohm Rowntree, em uma pesquisa que tratava de pensar as condições para a elaboração de uma legislação salarial mínima ao redor do mundo. Ao mesmo tempo, Gollancz editava uma série para a Oxford University Press, intitulada The World of Today. ${ }^{3}$

Apesar do dinamismo que o trabalho com Rowntree lhe provia, o que certamente lhe daria grande experiência no campo da pesquisa social empírica, o grande desejo de Gollancz, no entanto, era continuar com o trabalho iniciado ainda como estudante em Oxford, de promoção de cursos de civismo e sua implementação no currículo escolar. A breve experiência paralela como empregado da editora de Oxford mostrou a Gollancz, contudo, que era possível conciliar seus interesses pedagógicos com o trabalho de edição de livros. E foi com essa perspectiva que, em 1921, ele apresentou-se para uma vaga de trabalho na Benn Brothers Ltd. e acabou sendo contratado. 4

Gollancz foi empregado da Benn Brothers por 18 meses, na qual ocupou cargo no departamento de desenvolvimento técnico da editora. Uma divisão interna entre os sócios pouco depois, faria a companhia rachar. Dali foi criada a Ernest Benn Ltd., sob propriedade de um dos irmãos-sócios, e na qual Gollancz assumiu cargo de maior responsabilidade como diretor administrativo. Na nova função, Gollancz pode lidar com um empreendimento editorial muito mais amplo, voltado à publicação de uma gama variada de títulos e autores voltados ao grande público - a chamada "Sixpenny Series". Pela coleção, Gollancz pôde publicar livros de história, poesia, romances, peças teatrais, etc. Entre as publicações mais interessantes, estavam as cartas trocadas entre Gertrude Bell5 e H. G. Wells, sob o título de The

3 HODGES, Sheila. Gollancz: The Story of a Publishing House, 1928-78. London: Gollancz, 1979, p.15.

4 HODGES. Gollancz: The Story of a Publishing House, p.16.

5 Gertrude Bell (1868-1926) nasceu na cidade de Washington, no Reino Unido, e faleceu em Bagdá. Foi uma escritora, exploradora, diplomata, arqueóloga e espiã britânica que, diretamente empregada pelo Departamento Oriental do Foreign Office, atuou como emissária no Oriente Médio, trabalhando lado a lado com 
World of William Clissold, que ocupou três volumes, pela qual a editora pagou adiantado uma soma de 3.000 libras esterlinas - soma gigantesca para a década de 1920.

O crescimento de Gollancz dentro da Ernest Benn foi gradual e constante. Tanto que o próprio Ernest Benn viu seu poder decisório diminuir quanto ao controle editorial de sua própria firma, já que Gollancz, à frente do departamento editorial e liderando uma pequena mas leal equipe, era a cabeça pensante e os membros executores da editora. Com o desgaste, o resultado natural foi a saída de Gollancz da Ernest Benn Ltd. para fundar sua própria editora, em outubro de 1927.

No mesmo ano, Gollancz funda a Victor Gollancz Ltd. Desde o início, ele se valeria dos contatos e da experiência adquirida como agente literário em seu emprego anterior pela Ernest Benn. Com isso, logo nos primeiros anos, Gollancz conseguiu atrair importantes autores para o catálogo de sua nova editora, dentre eles A. J. Cronin, George Orwell, Ford Madox Ford, Fenner Brockway, H. Brailsford e o historiador G. D. H. Cole.

A Victor Gollancz Ltd. começou seus trabalhos no número 14 da Henrietta Street, em Covent Garden, local que concentrava inúmeras editoras e agentes literários desde o século XVIII e era considerada o principal endereço para aquele ramo de negócios do "West End" de Londres. O prédio que serviria como quartelgeneral da editora fora construído entre 1874 e 1875 para abrigar outra editora, a Williams \& Norgate, dirigida por Sidney Williams - sendo ocupado desde então apenas por editoras. A companhia de Gollancz iniciou seus negócios com um capital de 60 mil libras esterlinas, conseguido em empréstimos particulares. Seu sucesso anterior à frente da Ernest Benn Ltd. angariou a fé de amigos investidores de que seu novo negócio vingaria. ${ }^{6}$

E a própria fama de livreiro bem-sucedido já precedia os esforços de Gollancz à frente de seu empreendimento. Tanto que, em fevereiro de 1928, o jornal londrino Observer publicou propaganda em duas colunas com a lista dos livros (os primeiros) do catálogo da nova editora. Entres eles estavam, The Open Conspiracy, de H. G. Wells; a biografia Gladstone and Palmerston, de Phillip Guedallas; o livro de arquitetura, German Incunabula in the British Museum, de Stanley Morison; e uma edição em fac-símile do Book of Thel, de William Blake. Logo no primeiro ano de funcionamento, a Victor Gollancz Ltd. publicou um total de sessenta e quatro livros. E foi celebrada pelo mercado editorial londrino.?

Rapidamente, Gollancz fez de sua firma uma das editoras mais promissoras da Inglaterra e, na metade da década de 1930, já tinha lista de espera de autores interessados em serem publicados sob o selo da Victor Gollancz Ltd. Segundo Hodges, o sucesso de Gollancz deveu-se não apenas a sua capacidade como editor - e, claro, suas redes de contatos costuradas com o universo editorial londrino o beneficiariam demasiadamente -, mas a sua extrema astúcia administrativa para o negócio. Ele foi o primeiro a apostar em publicidade pesada para uma editora britânica, publicando semanalmente diversos anúncios em jornais de boa circulação - tais como o Observer e o Sunday Times - além de propaganda em outdoors, técnicas de comunicação praticamente ignoradas no mercado livreiro britânico. Essa relação comercial com a imprensa, Gollancz trouxe também de sua experiência anterior na Ernest Benn Ltd. Ali, ele já publicava pequenas notas diárias que

T. E. Lawrence junto ás tribos hachemitas da Península Arábica, para estabelecer um governo árabe independente da dominação otomana, que, no final, servia aos interesses britânicos para a região.

7 HODGES. Gollancz: The Story of a Publishing House. p.22. 
davam conta da relação entre a editora, seu catálogo e seus leitores - como críticas, sugestões e elogios à empresa e aos autores - algo sem precedentes, que revolucionou a indústria editorial britânica. ${ }^{8}$

As tarefas de composição desses anúncios eram divididas com seu tipógrafo, Stanley Morison, considerado um dos melhores à época, e que já havia trabalhado com Gollancz anteriormente na Ernest Benn Ltd. A participação decisiva de Morison se deu, contudo, na composição do design das "dust covers" que se tornaram marca registrada da Victor Gollancz Ltd. As "jackets" não eram usadas nos livros editados na Grã-Bretanha até a década de 1890. O fato interessante é que as primeiras publicações a adotarem uma capa externa ao livro - ainda como forma de simples proteção - foram editadas por um tio de Gollancz, o pesquisador da obra de Shakespeare, Israel Gollancz. ${ }^{9}$ No começo do século XX, "jackets" com imagens - agora já tomando um aspecto decorativo para "atrair a atenção do leitor" - começam a se popularizar na indústria tipográfica britânica. Para Gollancz e Morison, as cores de fundo das "dust jackets" deveriam compor, junto com as imagens e frases impactantes, um mix para destacar o nome do autor e o título da obra. A cor escolhida para compor o fundo, e que se tornou marca das edições da Victor Gollancz Ltd., foi o amarelo - a qual causou descontentamento entre alguns distribuidores por ficar com um aspecto "empoeirado" quando manuseado nas lojas. Como alternativa, foi escolhida uma combinação entre preto e vermelho briIhante (depois magenta), que perdurou para alguns títulos da editora. ${ }^{10}$

\section{Os anos da crise, a emergência do Popular Front e a fundação do Left Book Club}

Mesmo diante de toda a novidade para o mercado editorial britânico que Gollancz trouxe com a fundação de sua própria companhia, seu empreendimento intelectual mais audacioso, no entanto, foi a fundação do Left Book Club, em finais de 1935, também em Londres.

A criação do LBC esteve inserida em um movimento mais amplo de reação intelectual à conjuntura de crise que assolava a Inglaterra desde meados da década de 1920, catapultada pela organização do Popular Front. O clube seria um de vários empreendimentos culturais criados na tentativa de organização de uma frente ampla entre socialistas, comunistas e liberais como reação ao avanço do fascismo na Europa, tal qual imaginada nas linhas gerais da tática frentista elaborada pelo VII Congresso da Internacional Comunista no mesmo ano de 1935, em um momento em que as ideias socialistas começam a circular em circuitos mais amplos da sociedade britânica.

No início da década de 1930, o Communist Party of Great Britain (CPGB) contava com um número de 1.356 filiados, para, em 1938, atingir o número de 15.570 filiados. ${ }^{11}$ Muitos desses novos membros, advindos de estratos da classe média, onde inúmeros intelectuais se encontravam socialmente colocados. O início da participação em massa dos intelectuais na vida política britânica teve um efeito imediato

8 HODGES. Gollancz: The Story of a Publishing House. p.26

9 HODGES. Gollancz: The Story of a Publishing House. p.30

10 HODGES. Gollancz: The Story of a Publishing House. p.30

11 RODDEN, John. "On the Political Sociology of Intellectuals: George Orwell and the London Left Intelligentsia of the 1930s". Canadian Journal of Sociology/Cahiers canadiens de sociologie, v.15, n.3 (Summer, 1990), p.257. Disponível em: http://links.jstor.org/sici?sici=03186431\%28199022\%2915\%3A3\%3C251\%3AOTPSOI\%3E2.0.CO\%3B2-Z 
nas ideias que circulavam entre esses grupos. $O$ socialismo, então restrito ora aos sindicatos dos centros industriais britânicos, ora aos clubes fechados dos intelectuais universitários, durante o ápice da crise social da década de 1930, torna-se o leitmotiv para a fundação de inúmeras organizações e movimentos artísticos - entre grupos de teatro, produtoras cinematográficas, editoras, além de revistas e jornais. Grupos que tomam corpo em um movimento coletivo na cena pública, reivindicando novas formas de organização política para a Inglaterra, todas concebidas por meio dos ideais revolucionários socialistas. E o LBC rapidamente assume a vanguarda desse movimento, atingindo, já em 1938 (ou seja, apenas três anos após a fundação do clube), a soma de 57 mil associados, números anunciados na publicação oficial do clube, a revista Left News, servindo como guarda-chuva a esses intelectuais e suas atividades culturais. Cifras que indicavam o LBC como a maior organização política da Grã-Bretanha à época. ${ }^{12}$

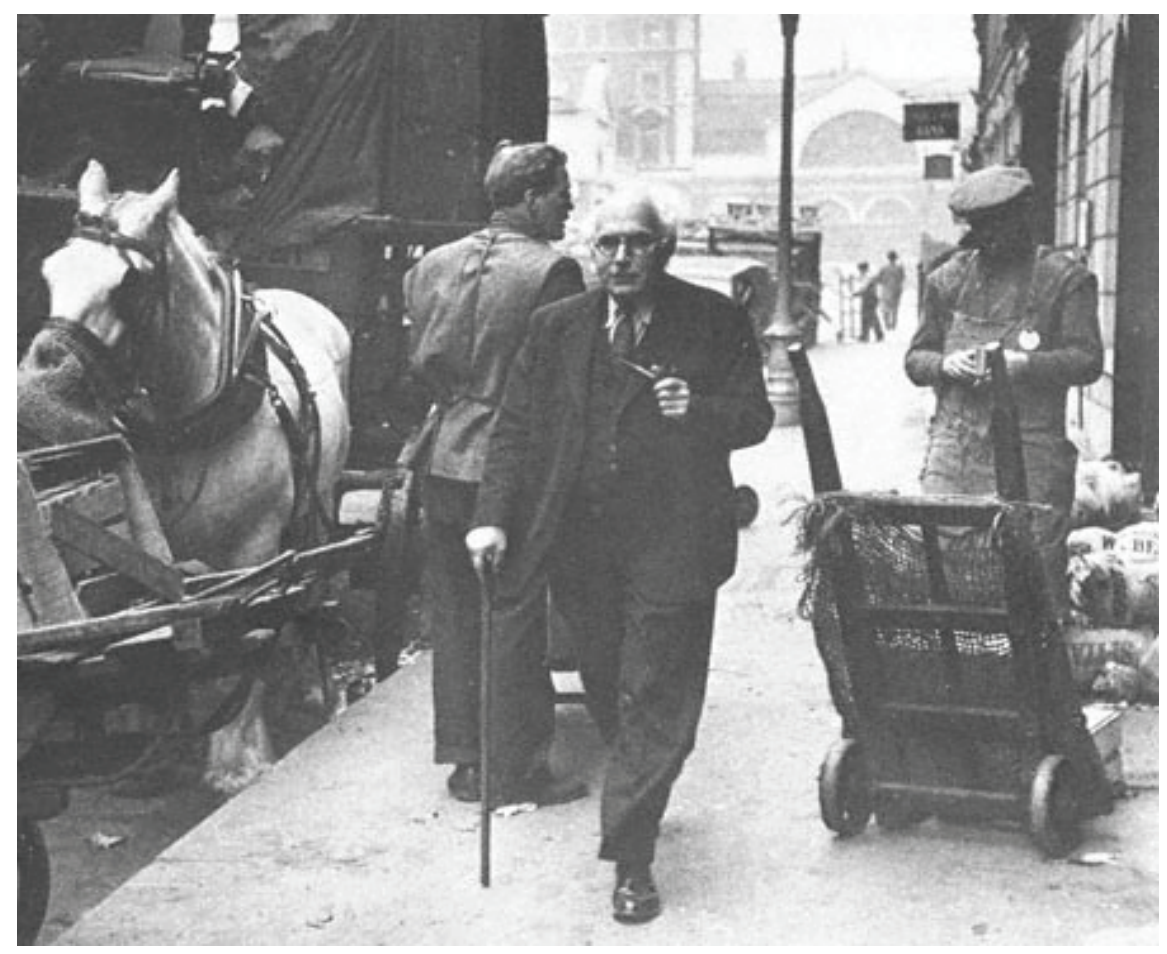

Victor Gollancz em Londres.

Gollancz funda o LBC com outros dois nomes de peso da cena intelectual britânica do entreguerras. Um deles era John Strachey (1901-1963), que foi membro do Labour Party, ao qual se filiou em 1923. Mais tarde, foi secretário-geral do New Party, dirigido por Sir Oswald Mosley. Com a aproximação do partido de Mosley do fascismo, Strachey se filiou ao CPGB, ainda no começo da década de 1930. Após a assinatura do Pacto Molotov-Ribbentrop e a invasão soviética da Finlândia, em 1939, Strachey afasta-se gradualmente dos comunistas. Ele retornaria ao Labour Party

12 Como indicou o relatório da Scotland Yard, de 17 de janeiro de 1938. (Pasta HO 144/21529. Home Office papers. The National Archives, Kew, Inglaterra) O crescimento do clube na década de 1930, dentro e fora da Inglaterra, foi alvo de preocupação direta de órgãos do Estado britânico, como o Home, o Foreign Office e a Scotland Yard que acompanharam passo a passo as atividades do LBC, especialmente antes da eclosão da Segunda Guerra Mundial. A preocupação do Estado britânico girava em torno dos contatos de Gollancz com membros do National Indian Congress, e outros contatos com as colônias. A ponto de todos esses órgãos estatais produzirem material constante sobre as atividades do clube no período. Tal material, ainda pouco explorado, me apresentou outra possibilidade de estudos das relações internacionais do LBC com o universo colonial, o qual pretendo explorar em pesquisa futura de pós-doutorado. 
em 1945, no qual permaneceria filiado até sua morte em 1963. O outro cofundador do LBC foi Harold Laski (1893-1950), economista e cientista político, professor da London School of Economics e presidente do Labour Party entre 1945-46. Junto com Gollancz, Stratchey pode se dedicar full time ao clube, escrevendo inúmeros artigos para a Left News e livros publicados pelo LBC. Para isso, recebia um salário semanal descontado no balanço geral do LBC. Já Laski conciliava suas outras funções com a de membro do corpo editorial do LBC, dando palestras e conferências nas reuniões organizadas pelo clube, escrevendo artigos também para a revista do clube.

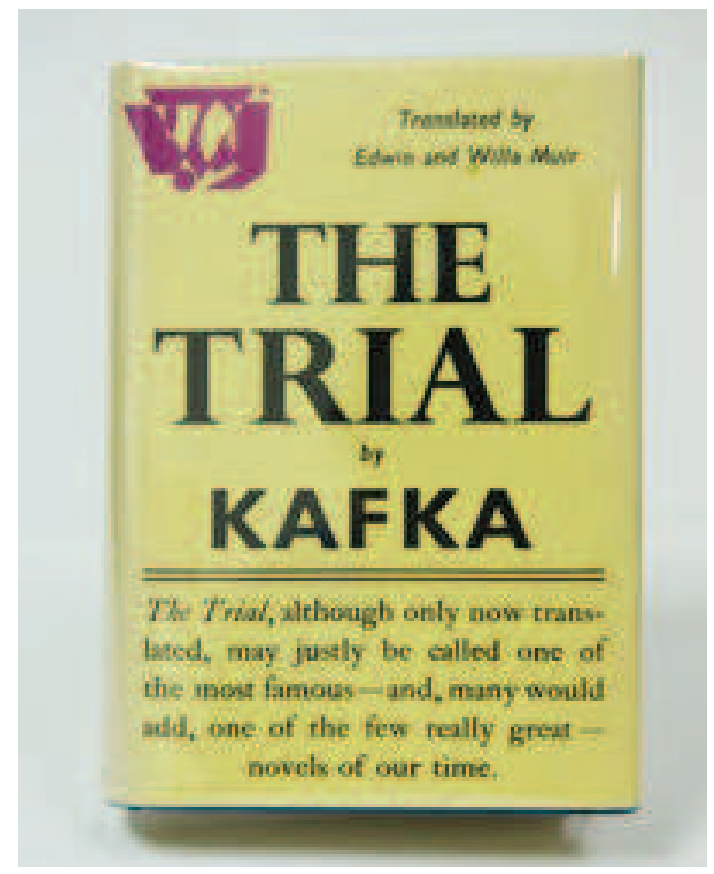

Capa do livro de Franz Kafka, "The Trial”, primeira edição em inglês e primeira edição inglesa da obra, traduzida direto do alemão por Edwin e Willa Muir, lançado pela Victor Gollancz Ltd. em 1937.

Organicamente, o LBC funcionava tendo como base logística a própria editora privada de Gollancz. No entanto, seu formato, inspirado em clubes do livro da Alemanha e dos EUA,,$^{13}$ permitiu a ampliação dos trabalhos, formando um círculo intelectual ao seu redor com a função básica de promover e difundir as ideias socialistas, primeiro de maneira mais ampla em Londres e, dali, para outros cidades na Inglaterra. Segundo o catálogo de títulos publicados entre 1936 e 1948, da coleção pertencente à University of Sheffield, na Inglaterra, o LBC publicou ao longo de seus anos de atuação enquanto editora cerca de 250 títulos diferentes. Indicações mais precisas entre os arquivos pessoais de Victor Gollancz, pertencentes à University of Warwick, também na Inglaterra, dão conta, no entanto, de exatos de 255 títulos publicados, disponibilizados de maneira exclusiva a seus assinantes e em edições especiais abertas a não membros. Até a eclosão da Segunda Guerra Mundial, eram oferecidos a seus assinantes dois títulos mensais: o título normal de cada mês e o chamado "livro do mês", escolhidos como uma edição especial para os membros, ao custo de 1/8 de libra por título, passando a disponibilizar um único título após

13 Gollancz se baseou na Book Society (fundada em 1921, http://www.thebooksociety.org.uk/about-us/) e na Collin's Crime Society (fundada em 1930, https://en.wikipedia.org/wiki/Collins_Crime_Club). Segundo Hodges, Gollancz acreditava ter criado a fórmula de distribuição de livros baratos em larga escala. Contudo, afirma ela, o American Book-of-the-Month Club (fundado em 1926, https://en.wikipedia.org/wiki/Book of the Month Club) e a Literary Guild (fundada em 1927, https://en.wikipedia.org/wiki/Literary Guild) já trabalhavam nesse esquema há anos, assim como vários clubes do livro alemães. (Hodges, 1978, p.127) 
1939, devido ao racionamento de papel na Inglaterra, que começou em março de 1940 e continuou até março de $1949 .{ }^{14}$

Analisando o catálogo pertencente à University of Sheffield, pudemos encontrar inúmeros nomes reconhecidos do público já à época ou que mais tarde viriam a ter preponderância no universo anglófono como romancistas, ensaístas e críticos. Podemos citar, sem contudo esgotar uma lista que é longuíssima, nomes como de romancistas e ensaístas tais como George Orwell, Arthur Koestler, Franz Borkenau, Herbert Read, Ignazio Silone, André Malraux; os poetas C. Day Lewis e Stephen Spender; os cientistas políticos Harold Laski, John Stratchey, Sidney e Beatrice Webb; cientistas como John Desmond Bernal, Hyman Levy e J.B.S. Haldane; políticos como Rajani Palm Dutt (então secretário-geral do CPGB); etc.

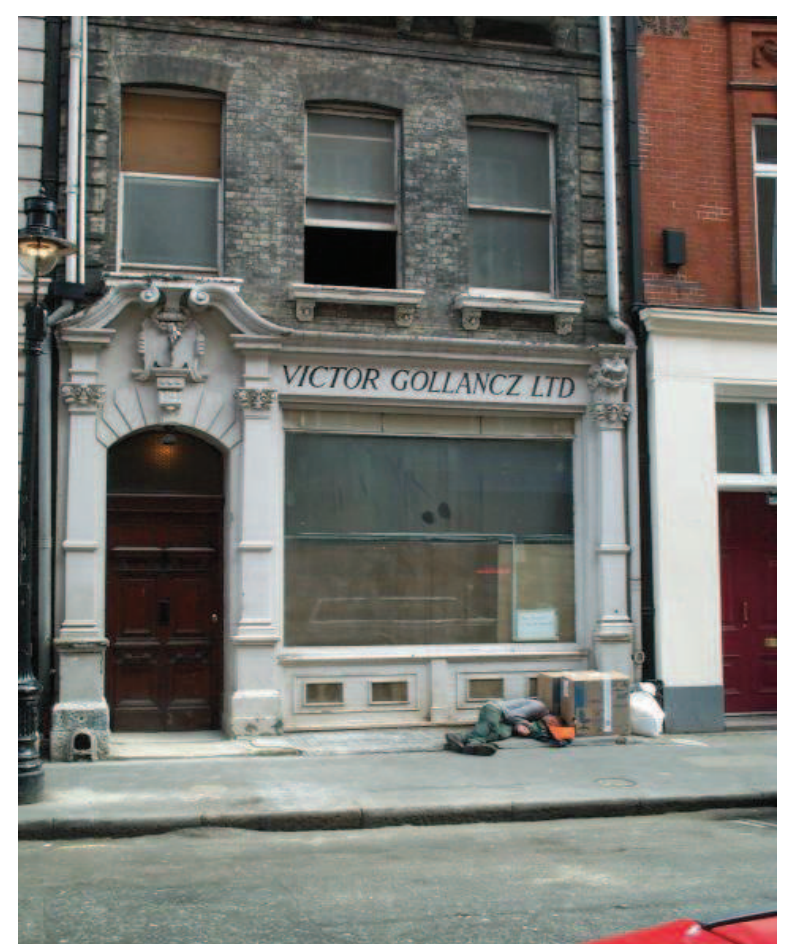

Escritório da Victor Gollancz Ltd., que funcionou no número 14, Henrietta Street, Covent Garden, no centro de Londres, entre 1927 e 1978.

O LBC distribuía ainda, mensalmente, para seus assinantes a revista Left News, que contou com 128 números, publicados entre 1935 e $1947 . .^{15}$ A revista

14 As informações sobre a organização do LBC e seu funcionamento podem ser lidas, por exemplo, na resposta (MSS.157/3/LB/2/6.i de 21 de novembro de 1956) à carta de Roy Hill (MSS.157/3/LB/2/5 de 20 de novembro de 1956), solicitando detalhes sobre a organização do LBC para um livro sobre o tema, em que a secretária de Victor Gollancz dá os seguintes detalhes: 1) o clube foi fundado em 1936, e foi, provavelmente, o primeiro clube do livro da Grã-Bretanha, precedido no modelo pelo Book Society; 2) o clube fechou as portas em novembro de 1948, quando o Labour Party ascendeu ao governo e a necessidade pelo modelo proposto pelo clube havia cessado; 3) o preço de venda dos livros distribuídos era usualmente 2/6 do preço de publicação para os assinantes; a edição do mês e a escolha do mês eram publicadas simultaneamente; os assinantes tinham que se credenciar por no mínimo seis meses e não podiam devolver os livros recebidos; havia ainda a possibilidade da escolha de outros títulos diversos, como livros educacionais, panfletos e assim por diante; 4) o número de títulos lançados pelo LBC foi de 255. Victor Gollancz Papers, Modern Records Center. University of Warwick.

15 A coleção da University of Sheffield reúne também boa parte das edições da revista Left News em microfilme. Nela estão disponíveis os números 15 (1937) e 21 a 128 (1938 a 1947), faltando então os primeiros 14 números da revista. Devo agradecer toda a ajuda despedida pelo staff da Special Collection da Western Bank Library, da University of Sheffield no apoio à minha pesquisa entre seus arquivos, em especial ao seu arquivista, Chris Loftus. 
permitiu expandir os temas discutidos pelos membros do LBC, além de servir como uma plataforma de interação entre o clube e seus assinantes, muitos deles com ligações diretas com o CPGB, o Labour Party, o Independent Labour Party e outras correntes da esquerda britânica.

Como vimos acima, o LBC serviu também como órgão de organização cultural, participando na montagem de peças teatrais, seções de leituras, mostras artísticas, grupos de discussão, etc. Para se ter ideia do alcance desse trabalho, apenas a Theater Guild, patrocinada pelo LBC, financiava cerca de 250 companhias de teatro amador, produzindo montagens de cunho social tal qual a famosa peça do autor estadunidense Clifford Odets, Waiting for Left, que ficou famosa durante a ascensão do Popular Front nos EUA. A peça de Odets seria ainda escolhida como suplemento a ser publicado pelo clube em junho de 1937.

\section{A expansão do Left Book Club dentro e fora da Inglaterra: a internacionalização de um projeto de educação das classes trabalhadoras}

O crescimento dos grupos aglutinados ao redor do LBC foi gradativo ao longo de seus primeiros anos de funcionamento. Na edição da revista Left News de julho de 1937, por exemplo, há uma lista indicando o endereço de 600 círculos locais do LBC em toda a Grã-Bretanha (onde há referências sobre os clubes de Leeds, Liverpool, Wolverhampton, Cambridge, etc.). ${ }^{16}$ Na Left News de janeiro de 1938, o número de círculos ligados ao clube é anunciado como mais de 800, ou seja, 200 a mais do que os anunciados na edição de julho de 1937. Já no número 36, de março de 1939, era anunciado o crescimento para 1.500 grupos aglutinados ao redor do $\mathrm{LBC},{ }^{17}$ o que mostra um crescimento significativo do clube em um espaço de menos de dois anos. ${ }^{18}$ Outro dado interessante que pode ser lido nas edições da Left News é a atenção que Gollancz e seus sócios davam ao crescimento gradual do número de assinantes do LBC. Um exemplo é o número 21, de 21 de janeiro de 1938, que apresentou números relativos ao crescimento dos assinantes do clube entre 1936 e 1938. Essa edição da revista traz um gráfico detalhado indicando que, entre janeiro e abril de 1938, o clube ganhara mais 7 mil novos assinantes. Marca que nem mesmo os organizadores do clube esperavam com a venda mensal de "livros de esquerda". ${ }^{19}$ Fica claro assim que, mais do que criar outros grupos, o LBC aglutinou grupos já existentes ao seu redor - muitos que já faziam trabalho cultural em suas cidades e outros que surgiam ao longo década de 1930.

Na mesma edição de 21 de janeiro de 1938 da Left News, o editorial assinado por Gollancz explicava a seus leitores ainda a função dos grupos de leitura organizados ao redor do LBC: discutir as escolhas de cada mês para os títulos especiais publicados pelo clube..$^{20} \mathrm{~A}$ Left News tinha, com isso também, clara função organizacional: apresentava aos membros do LBC não apenas a estrutura de funcionamento dessa máquina cultural - apresentando, por exemplo, balanços financeiros, dados de crescimento e evolução do público ao redor da rede costurada pelo clube, etc. -

16 “Left Book Club Summer School”. Left News, n. 14, 15 jul. 1937, p.436.

17 Left News, n.36, mar. 1939. p.1119.

18 Left News, n.21, 21 jan. de 1938, p.704.

19 "The membership: 7.000 new members 'net' from the end of January to end of April". Left News, n.21, 21 jan. 1938, p.831.

20 “Editorial”. Left News, n.21, 21 jan. 1938, p.661. 
como também apresentava seu conteúdo programático, como a agenda mensal ou semanal dos vários grupos em torno do clube, suas atividades e propostas, etc.

Ao acompanhar as atividades dessa rede costurada ao redor do LBC por meio dos vários editoriais, resumos de atividades, anúncios de eventos futuros, etc., um leitor atento poderá ver o nascimento de inúmeros grupos que foram fundamentais na difusão e circulação das ideias dentro do movimento socialista britânico. No número 14, de julho de 1937, da Left News, por exemplo, há referência sobre a fundação de um grupo de cientistas encabeçado por Hyman Levy, dando conta, possivelmente, do início dos trabalhos do movimento Social Relations in Science, ${ }^{21}$ cujos debates posteriores em torno do papel do marxismo para as ciências duras iriam forçar as tentativas de alargamento da teoria marxista para além das fronteiras impostas pela ortodoxia CPGB. Apesar de mais tarde o grupo da SRS ter se organizado em torno da revista The Modern Quarterly, reconhecida como a publicação mais importante para o debate teórico do marxismo na Inglaterra da primeira metade do século XX, o nascimento do movimento de "cientistas verme-lhos", como ficaram conhecidos mais tarde alguns dos mais brilhantes nomes das ciências britânicas, como J.B.S. Haldane, John Desmond Bernal, H. Levy, Joseph Needham, etc., pode ser acompanhado de perto pelos debates travados em torno do LBC.

É possível notar, dessa forma, que o LBC representou um importante papel na própria organização do Popular Front britânico por meio de inúmeras iniciativas pedagógicas de difusão das ideias socialistas e organização de centros de leitura, grupos de estudo, etc. As chamadas "Summer Schools", organizadas mensalmente pelo clube, refletiam claramente essa preocupação em educar a classe trabalhadora, como era reiteradamente declarado por Gollancz, especialmente nos editoriais da Left News. Os encontros geralmente organizados em duas semanas de cada mês, consistiam em dois períodos no qual se debatiam textos pré-definidos pelos organizadores: o primeiro, pela manhã, com "lectures", e uma seção à tarde, com a "discussion", separadas por uma hora e meia de intervalo. A estrutura de um desses encontros seria apresentada, por exemplo, no número 15, de 15 de julho de 1937 da revista Left News. Essa edição dava conta da "Summer school" que ocorreria entre os dias 31 de julho e 14 de agosto de 1937, para a qual estavam programadas aulas e discussão de títulos publicados pelo LBC, como G.D.H. Cole e J.D. Bernal, além de títulos publicados por membros do staff organizacional do clube, como John Lewis e John Strachey. ${ }^{22}$

O projeto de "educação política das classes trabalhadoras" era um dos desafios tácitos do LBC, como foi declarado pelo próprio Gollancz em editorial para o número 22, de fevereiro de 1938, da Left News em que eram apresentados aos assinantes as "tarefas" do clube para aquele ano:

(...) A segunda etapa do trabalho neste ano [...] será fornecer instalações para uma educação política mais sistemática e mais profunda para os nossos membros. Acreditamos que chegou o momento para complementar as publicações do Clube, e as discussões nos grupos locais com base nelas, por uma série de aulas cuidadosamente planejadas, a partir do qual deve emergir um grupo de militantes altamente educados e também quadros de líderes capazes de guiar-nos para a vitória. Os membros do Clube que utilizarem estas instalações se tornarão, se posso colocá-lo assim, a elite, as tropas de choque, de nosso movimento. ${ }^{23}$

21 "Special groups". Left News, n.14, 15 jul. 1937, p.432.

22 Left News, n. 15, 15 jul. 1937, p.451.

23 (...) Our second major piece of work this year, as I also announced at the Convener's Conference and the 
É interessante notar que, paralelo ao papel pedagógico assumido pelo LBC certamente herdeiro das experiências de Gollancz em seus anos em Oxford - havia ainda outra função importante a ser desempenhada pelo clube: servir como instrumento de propaganda das ideias socialistas. $\mathrm{O}$ objetivo era produzir livros baratos e com um conteúdo claro, com temas atuais e diversidade de discussão. Gollancz, além de insistir no papel do LBC como um instrumento propagador das ideias socialistas, aglutinava seus leitores para ajudá-lo na empreitada, como escreve ainda na mesma edição de fevereiro de 1938, da Left News:

(...) [O objetivo d'] A criação das aulas políticas será completar o processo de aprendizagem: ao mesmo tempo que temos de converter os membros mais ativos do clube em um corpo consciente de missionários e professores. Os membros já estão, é claro, fazendo uma quantidade tremenda de tal trabalho em sua própria maneira: e ações individuais desse tipo provavelmente devem permanecer como o principal método pelo qual avançaremos. (...) Mas queremos completar esta atividade através da conversão de nossos membros em uma máquina de distribuição, através da qual iremos fornecer a primeira abordagem para os indiferentes, os ignorantes e até mesmo os vagamente hostis, e que será tão barato que alguns membros vão se sentir capazes de comprá-los em [grandes] quantidades, e distribuir-Ihes. ${ }^{24}$

A Left News dá conta ainda da internacionalização desse projeto de educação das classes trabalhadoras para fora da Inglaterra. As conexões internacionais de Gollancz facilitaram a extensão dos trabalhos do clube para outras regiões, em especial, aquelas conectadas pelo Império britânico. O que motivou a criação de outros clubes, baseados no modelo do LBC, pelo mundo. A documentação existente nos arquivos britânicos consultados dão notícias então da criação de filiais do LBC na Austrália, Canadá, China, África do Sul, Índia, Noruega, Bélgica, França, Palestina, Israel, Chile, etc. ${ }^{25}$

A título de exemplo, o caso do The Current Affairs Group, o braço local do LBC na Rodésia do Sul, é interessante. O grupo foi fundado em 1938 sob influência direta de Victor Gollancz para apoiar a causa republicana da Guerra Civil Espanhola. Junto com o jornal comunista sul-africano Guardian, o The Current Affairs Group era responsável por disseminar as ideias socialistas entre a população negra, segregada pelo Apartheid, como parte integrante de um projeto mais amplo da alfabetização e educação popular baseado no modelo implementado pelo LBC na Inglaterra. Além da possibilidade da circulação das edições produzidas pelo

Rally, will be provided facilities for a more systematic and more profound political education for our members. We believe that the time has come to supplement the publication of the Club, and the discussions in the local groups based on them, by a series of a carefully planned class, from which there should emerge both highly educated rank and file and also cadres of leaders capable of guiding us to victory. Members of the Club who avail themselves of these facilities will become, if I may put it so, the elite, the shock troops, of our movement. GOLLANCZ, "Political education classes". Left News, n.22, fev. 1938, p.678.

24 (...) The setting up of the political classes will be complete the process of learning: simultaneously we have to convert the more active Club members into a conscious body of missionaries and teachers. Members are, of course, already doing a tremendous amount of such work in their own way: and individual action of this kind must probably remain the chief method by which we will do our proselytism. (...) But we want to supplement this activity by converting our membership into a distributing machine by which will provide the first approach to the indifferent, the ignorant and even the vaguely hostile, and which will be so cheap that some members will feel able to purchase them in quantities, and given them away. GOLLANCZ, "Political education classes". Left News, n.22, fev. 1938, p.679.

25 Ver, por exemplo, a carta de Arthur Key (da Middle East Press Service, situada em Londres) para Victor Gollancz, de 11 de Junho de 1945, perguntando sobre a possibilidade de desenvolver a circulação do Left Book Club no Egito e na Palestina, através do contato com Robert Schindler, editor da Middle East Press para o Cairo. (MSS.157/3/LB/1/2, Victor Gollancz Papers, Modern Records Center, University of Warwick) 
LBC, essas redes internacionais demandavam também a disseminação da Left News por entre os leitores, ${ }^{26}$ ampliando assim as redes do LBC para circuitos internacionais. ${ }^{27}$

Essas redes transnacionais costuradas pelo LBC ao redor do mundo criaram laços entre os intelectuais britânicos e diversas causas fora da Europa, como as lutas de independência das colônias britânicas na África e Ásia, o movimento de independência indiano, a questão palestina e os primeiros assentamentos judaicos na região, etc. Todos esses temas seriam debatidos também em artigos para a Left News. O contato entre os membros do LBC com o movimento nacional indiano, por exemplo, foi tão grande que despertou o interesse do Foreign Office e da Scotland Yard, ao ponto dos dois órgãos produzirem um consistente material documental sobre as atividades do clube dentro e fora da Inglaterra - incluindo listas de livros lançados pelo LBC que deveriam ter suas publicações proibidas; ${ }^{28}$ a relação de intelectuais reunidos em torno do clube com o movimento nacional indiano ${ }^{29}$ e a participação de indianos nos comícios, manifestações e encontros organizados pelo LBC em Londres..$^{30}$

\section{Gollancz editor e mediador}

Às vésperas da Segunda Guerra Mundial, como vimos, o Left Book Club já era considerado o maior grupo político do país, servindo como guarda-chuva de um vasto leque de atividades voltadas à classe trabalhadora, construindo um movimento amplo que a esquerda britânica, até aquele momento, jamais havia presenciado. Além disso, o trabalho de Gollacz havia ganhado repercussões internacionais por meio da difusão internacional do material produzido pelo LBC. Quais eram, no entanto, as posições pessoais de Gollancz em meio a esse universo cada vez mais vasto de ideias e pessoas que seu trabalho como livreiro e editor passou a congregar ao, longo da década de 1930, diante do crescimento do LBC e da Victor Gollancz Ltd.?

Talvez um caminho para responder a esta pergunta seja retomar as funções de Gollancz como editor do LBC. Função que lhe atribuía também a obrigação de atuar como mediador entre os autores que publicavam pelo clube, o público assinante e, de maneira mais ampla, o círculo intelectual congregado ao redor do LBC. E dois casos específicos podem iluminar esse caminho. Um deles foi o de George Orwell, cujo livro The Road to Wigan Pier foi publicado como "livro do mês" pelo LBC em março de 1937. O outro foi Leonard Woolf, cujo livro Barbarians at the Gate, foi a escolha do mês de novembro de 1939.

26 Ver, por exemplo, a carta do padre R. Conesa (MSS.157/3/LB/1/13, Victor Gollancz Papers, Modern Records Center, University of Warwick), bibliotecário do St. Xavier College, Bombaim, Índia, de 25 de outubro de 1945 , sobre a assinatura da revista Left News, comentando brevemente o interesse pelos temas debatidos na revista e a publicidade que ela poderia alcançar ali, local com 2.500 alunos, segundo ele. Da mesma forma é a requisição de Feroze S. Wadia, em carta de 7 de janeiro de 1946, em que é solicitada o envio de cópias gratuitas da Left News para Bombaim, na Índia, em troca de publicidade gratuita da revista por lá. MSS.157/3/LB/1/15, Victor Gollancz Papers, Modern Records Center, University of Warwick.

27 SAMUELS, Stuart." The Lef Book Club". Journal of Contemporary History, v.1, n.2, Left-Wing Intellectuals between the Wars (1966), p.83. Disponível em: http://www.jstor.org/stable/259923.

$28 \mathrm{CO}$ 273/633/1 Descrição: “Left Book Club, London: prohibition of publications". London: The National Archives, Kew, 1937.

29 IOR/L/PJ/12/504: Arquivo 1025/36. Descrição: "The Left Book Club: reports on members, activities and Indian interests' (Dec 1936-Feb 1938)". London: The National Archives, Kew.

30 HO 144/21529 Descrição: “Disturbs”: “Reports on the activities of the 'Left Book Club”". London: The National Archives, Kew, 1936-1941. 
Gollancz fora o primeiro editor de Orwell, editando seis dos sete livros do autor publicados na década de $1930 .{ }^{31}$ Além disso, o editor deteve os direitos de publicação da obra de Orwell até 1946, recusando, depois da publicação do The Road to Wigan Pier, vários outros trabalhos do autor. Entre eles, dois dos livros de maior notabilidade da carreira de Orwell: o Homage to Catalonia, sobre a Guerra Civil Espanhola, que seria lançado em 1938, e, sete anos depois, o Animal Farm, publicado em 1945 - ambos recusados por Gollancz por seu conteúdo anti-stalinista. Orwell só conseguiria se "libertar" do contrato com Gollancz após acertar com outro editor britânico, Frederic Warburg, que passou a ser seu editor na Inglaterra a partir de 1946, e o foi até o final de sua vida, em 1950.

Orwell só publicou um livro sob o selo do LBC: The Road to Wigan Pier, em março de 1937. O livro foi o resultado de uma reportagem encomendada pelo LBC com fins de proporcionar um retrato das condições de vida e trabalho dos mineiros das cidades de Yorkshire e Lancashire, no norte da Inglaterra devastada pela crise da década de 1930. Orwell dividiu seu livro, no entanto, em duas partes: na primeira, analisa em tom de narrativa jornalística a situação de miséria, desnutrição, insalubridade e abandono de várias famílias de mineiros nas regiões industriais da Inglaterra; na segunda, sob um tom autoral, a análise se torna uma dura crítica à intelligentsia de esquerda em seu país.

A repercussão do livro de Orwell foi imediata entre o público do LBC, sendo notabilizado como um dos que mais gerou cartas dos assinantes do clube. Gollancz tratou de apaziguar os ânimos com a inclusão de uma "nota introdutória" à edição lançada apenas para os membros assinantes do LBC. ${ }^{32}$ Na nota, é possível ler ainda uma clara tentativa de Gollancz em se distanciar, e ao LBC, das opiniões de Orwell e sua visão sobre a esquerda em seu país. Mesmo com as críticas, o livro de Orwell foi escolhido como o livro do mês de março pelo LBC, sendo republicado em segunda tiragem em maio do mesmo ano.

Vale a pena, de maneira resumida, sumarizar alguns pontos que me parecem centrais na argumentação de Gollancz na nota introdutória ao The Road to Wigan Pier. Mais especificamente por que ali, o editor dá conta do ambiente em que os debates da esquerda britânica se davam na década de 1930, e os cuidados que Gollancz deveria ter ao conduzir o LBC em um terreno tão sensível.

Nas palavras de Gollancz na introdução ao livro de Orwell, o LBC tinha como intenção criar "as bases de massa" sem a qual uma "genuína Frente Popular" seria impossível de se estabelecer. Nessa afirmação, há dois aspectos que podemos considerar. O primeiro é justamente a ideia da criação de uma "base de massas", ou seja, de um público pronto para receber e deglutir as ideias socialistas que ganham repercussão na década de 1930, em grande parte, favorecidas pela depressão e a falência das políticas liberais. Vê-se aí, uma vez mais, uma intenção quase pedagógica em educar esse "novo público" (ou seja, as classes trabalhadoras) para a compreensão dessas novas ideias que circulavam. E daí criar "bases populares" com fins de promover a ascensão do socialismo na Inglaterra.

31 Orwell publicou, na década de 1930, sob o selo da Victor Gollancz Ltd., os seguintes livros: Down and Out in Paris and London (1933), Burnese Days (1935), Clergyman's Daughter (1935), Keep the Aspidistra Flying (1936) e Coming Up for Air (1939). Além disso, publicou a coleção de ensaios Inside the Whale (1940).

32 O livro The Road to Wigan Pier foi lançado pela primeira vez em 1937, pela editora dirigida por Gollancz simultaneamente em edição pública e em edição especial para os membros do Left Book Club, em tiragem de 43.000 cópias. MEYERS, Jeffrey (org.). George Orwell: The critical heritage. London, Boston: Routledge \& K. Paul, 1975. p.12. 
É importante lembrar ainda que The Road to Wigan Pier é lançado em Londres no calor na Guerra Civil Espanhola e sua influência é clara nas palavras de Gollancz sobre o trabalho de Orwell. É interessante pensar então que o cuidado de Gollancz com as críticas de Orwell à esquerda naquele livro estava ligado também ao contexto em que os comunistas eram criticados por sua atuação na Espanha. O que nos remete ao segundo ponto que podemos desdobrar da nota introdutória ao The Road to Wigan Pier: as implicações das "Frentes Populares" para a Inglaterra. O modelo proposto pelo VII Congresso da Internacional Comunista em 1935 e que se estabeleceu em termos práticos ao longo dos anos da guerra na Espanha, gerou uma série de debates nos círculos da esquerda pela Europa. Tanto anarquistas, quanto certa parte da esquerda, discordavam dessa forma de organização para o combate ao fascismo e a Franco, devido, especialmente, à centralização do comando das Frentes Populares espanholas nas mãos comunistas das brigadas internacionais e, consequentemente, da URSS. Para outra parte da esquerda, inclusive aquela em que Gollancz estava inserido, o modelo das Frentes Populares na revolução social na Espanha se estabeleceu como uma organização genuinamente popular, e poderia servir também à Inglaterra.

É interessante destacar, no entanto, que a relação de Gollancz com a Guerra Civil Espanhola, paralela à sua função como editor do LBC, foi também de um conciliador de ânimos. O clube publicou importantes trabalhos que relatavam os acontecimentos na Espanha quase que em primeira mão, como o livro de Arthur Koestler, Spanish Testament, lançado pelo clube em dezembro de 1937, além de uma série de artigos e números especiais da Left News dedicado à guerra civil. Outros, como o livro de Isabel Oyazar'bal, Smouderling freedom: the story of the Spanish republicans in exile, publicado em 1946, tratavam da questão dos refugiados da guerra. Quanto à temática dos refugiados espanhóis, Gollancz teve papel ainda mais decisivo quando empregou o aparato do LBC na campanha popular promovida por vários setores da esquerda britânica para arrecadação de fundos a fim de bancar o envio de ajuda humanitária às vítimas da guerra. Campanhas que ajudaram na criação da Spanish Medical Aid Committee, em agosto de 1936 e do National Joint Committee for Spanish Relief, em novembro do mesmo ano. O papel de Gollancz foi fundamental ainda para a campanha de acolhimento dos órfãos bascos na Grã-Bretanha, cujo resultado final foi o desembarque de 4.000 crianças bascas na Inglaterra em maio de 1937.33 Paralelamente, Gollancz tentava apaziguar as críticas aos comunistas publicadas por membros do LBC, como Frank Jellinek e Orwell. A crítica de Orwell contra a atuação soviética na Espanha, embutida em sua análise pessoal do problema espanhol, fez Gollancz recusar a publicação de um dos livros que mais chamaria a atenção sobre a guerra civil entre aquela geração: o Homage to Catalonia, que seria publicado em 25 de abril de 1938 pela editora Secker and Warburg, em Londres.

Mesmo exercendo esse papel de mediador de conflitos entre opiniões divergentes entre os membros do LBC, Gollancz não parecia ter qualquer pretensão dogmática em homogeneizar o discurso crítico provindo de dentro do clube. Com isso podemos pensar o Left Book Club também como um rico fórum de debates entre a esquerda de Londres congregada em torno de seus trabalhos. As várias tensões criadas nas discordâncias político-ideológicas que surgiram desses debates tinham como suporte o próprio clube, que publicou inúmeras vezes livros e artigos através da Left News, em que autores que publicavam pelo clube discordavam entre si em relação às suas análises sobre a conjuntura daquele momento. 
E o período que antecedeu a entrada da Inglaterra na Segunda Guerra Mundial foi de especial importância, pois dividiu os autores em torno do clube entre aqueles que suportavam o stalinismo e um grupo já declaradamente anti-stalinista desde a Guerra Civil Espanhola - como no caso de Orwell, Arthur Koestler, Frank Jellinek e outros. No final da década de 1930 e com o avanço sistemático do fascismo, manter ou não uma ligação com a URSS se tornou questão-chave nos debates da esquerda londrina.

No entanto, com a face autoritária do stalinismo sendo revelada (mesmo que, anos antes, as denúncias daqueles que estiveram na Espanha tivessem sido duramente criticadas), o suporte dos intelectuais britânicos à URSS no final da década de 1930 já não podia ser simplesmente baseado no argumento da luta entre ideologias opostas. Como ignorar então a assinatura do pacto de não-agressão germano-soviético, em 1939, seguido da invasão da Polônia e da declaração da guerra mundial? Em resposta a essas indagações, em novembro de 1939, a escolha do mês do LBC foi o livro de Leonard Woolf, Barbarians at the Gate. O livro veio carregado de duras críticas à política externa soviética. John Strachey respondeu duramente ao livro de Woolf em artigo para a revista Left News, em sua edição de novembro de $1939 .{ }^{34} \mathrm{E}$, por sua vez, Strachey foi duramente criticado por Harold Laski em artigo seguinte da Left News, no número de dezembro de 1939.

O livro de Woolf e o debate acalorado que gerou entre os editores do LBC ilustram bem as relações do clube com a política mainstream da esquerda britânica quando a Inglaterra caminhava pelo caminho irremediável da entrada na guerra contra a Alemanha. Tal qual ocorrerá com o livro de Orwell, o livro de Woolf também foi uma encomenda direta de Gollancz, cuja primeira proposta seria enviada em carta para Woolf, em 19 de outubro de $1938 .{ }^{35} \mathrm{Na}$ carta, Gollancz fala ainda sobre os principais objetivos do LBC às vésperas da entrada britânica na guerra contra o nazismo, indicando que a mudança da política internacional depois do pacto de não agressão entre Hitler e Stalin provocara uma mudança na sua própria concepção sobre os caminhos para o socialismo. O trecho da carta que destaco abaixo ilustra bem essa mudança de perspectiva pessoal de Gollancz:

Durante os dois anos e meio de sua existência, o Left Book Club tendia em suas publicações a concentrar-se (mais ou menos) em dois temas: a) o perigo do fascismo; b) a necessidade do socialismo. Enquanto eu acho que deve continuar a dar grande ênfase ao primeiro e alguma ênfase para o segundo, creio que, no que eu considero como a nova situação criada por Munich, deve, no futuro, dar, pelo menos, tão grande, e talvez maior, ênfase a um terceiro tema. ${ }^{36}$

Contextualmente, a grande decepção causada depois da assinatura do pacto de não agressão entre Hitler e Stalin em 1939, forçou uma parte da esquerda que

34 STRACHEY, J. "Barbarian at the Gate - a critique". Left News, nov. 1937, p.1398-1342.

35 Todas as referências às cartas trocadas entre Gollancz e Woolf relativas à publicação do livro "Barbarians at the Gate" (1939) pertencem à pasta SxMs-13/1/L/3/1 da coleção sob guarda da University of Sussex and Brighton and Hove Royal Pavilion Museum Records. Os arquivos da pasta, no entanto, não apresentam referências individuais em cada folha ou grupo de folhas, por exemplo, em cartas com mais de uma página. Por isso, faço essa referência geral à pasta em que os documentos podem ser encontrados.

36 "During the two and a half years of its existence, the Left Book Club tended in its publications to concentrate (more or less) on two themes - a) the danger of fascism; b) the necessity of socialism. While I think it must continue to give great emphasis to the first and some emphasis to the second, I believe that, in what I regard as the new situation created by Munich, it must in future give at least as great, and perhaps greater, emphasis to a third theme." Gollancz para Woolf, 19 de outubro de 1938, University of Sussex and Brighton and Hove Royal Pavilion Museum Records. 
militava dentro do Popular Front mundo afora a retomar suas relações com as ideias liberais, especialmente com a defesa de um sentido de democracia - muito mais estrito à defesa de alguns conceitos liberais, como o de liberdade de expressão e pensamento, do que ao modelo grego de "governo do povo" - que parecia contrariar o alinhamento ideológico do stalinismo com o fascismo. E Gollancz continua em sua carta a Woolf, nesse sentido:

Sinto-me em dúvida agora se esse ponto de vista foi sempre o correto: mas se era ou não, minhas próprias ideias sobre o assunto foram alteradas pela nova situação em que nos encontramos. Eu acredito que aqui e agora, sem qualquer compromisso, essas "ideias liberais" têm de ser imediatamente defendidas e preservadas. Se isso não puder ser feito, vejo a extinção de tudo de decente na humanidade. ${ }^{37}$

A ideia sugerida por Gollancz a Woolf era um livro mais ou menos chamado Em defesa da sociedade ocidental, como um contraponto do livro de Aurel Kolnai, The war against the West, publicado pelo LBC em julho de 1938. Nesse sentido, o livro de Woolf deveria abordar o socialismo de um ponto de vista liberal, o que, na visão de Woolf, abria caminho para uma crítica ao stalinismo..$^{38}$ Depois de longas cartas trocadas entre Woolf e Gollancz, a fim de acertar os detalhes do livro, por fim, Woolf envia uma cópia do manuscrito à Gollancz, em 9 de maio de 1939. O título escolhido para o livro foi: The Barbarians at the Gate.

A repercussão interna, entre os editores do $L B C$, do livro de Woolf foi imediata. ${ }^{39}$ Strachey havia repudiado completamente a possibilidade do livro ser transformado em "escolha do mês" do LBC, já que apresentaria pontos extremamente inconclusivos e difíceis de serem defendidos de ataques "reacionários". Já Laski considerava que ele podia se transformar na "escolha do mês" desde que sob grande alterações - muitas delas já sugeridas pelo próprio Gollancz, como a troca de algumas palavras para que não tivessem seu significado "confundido". A proposta de Gollancz, mediando todas as opiniões, mas exercendo seu poder como editor-chefe foi a seguinte: Strachey revisaria o livro em artigo para a Left News e essa resenha seria enviada a Woolf. No meio tempo, o próprio Gollancz e Laski comporiam suas próprias resenhas. Depois disso, haveria uma reunião onde todos os editores discutiriam cada um sua leitura do livro de Woolf e dali deveria sair uma proposta de algumas alterações - ou "acréscimos", como sugere Gollancz. E por fim, após muitos rearranjos, Woolf recebe a confirmação, em carta enviada por Gollancz de 29 de setembro de 1939, de que seu livro seria, por fim, a "escolha do mês" de novembro de 1939 do LBC.

37 "I feel doubtful now whether that point of view was ever right: but whether it was or not, my own ideas on the subject have been altered by the new situation in which we find ourselves. I believe that here and now, without any compromise, these "liberal ideas" have got to be immediately defended and preserved. If this cannot be done, I see the extinction of everything decent in humanity." Gollancz para Woolf, 19 de outubro de 1938, University of Sussex and Brighton and Hove Royal Pavilion Museum Records.

38 Foram três cartas trocadas entre Woolf e Gollancz em relação à negociação do livro. Todas as referências as cartas trocadas entre Gollancz e Woolf relativos à publicação do livro "Barbarians at the Gate" (1939) pertencem à pasta SxMs-13/1/L/3/1 da coleção sob guarda da University of Sussex and Brighton and Hove Royal Pavilion Museum Records.

39 E Gollancz repercute a leitura de Strachey e Laski em carta para Woolf de 22 de junho de 1939. 


\section{A Segunda Guerra Mundial e a consolidação da figura pública de Victor Gollancz}

Às vésperas da Segunda Guerra Mundial, já estava consolidado o papel público exercido pelo LBC em meio ao Popular Front. Desde o final da década de 1930, o clube tinha papel central na organização de uma série de eventos públicos, alguns de grande escala, tais como os comícios anuais que aconteceram em Londres pouco antes da entrada da Grã-Bretanha na guerra: em 1937, o comício de Albert Hall; em 1939, o comício de Queen's Hall; e o comício no Express Stadium, que reuniu 10 mil espectadores ávidos para ouvir diversas falas sobre várias correntes da esquerda. Essas atividades quase que automaticamente elevaram a figura de Victor Gollancz a um patamar sólido entre as principais figuras políticas do período. E, de fato, a correlação entre a história particular de Gollancz e a atuação do LBC são exemplos de um processo de engajamento intelectual na vida pública, antes mesmo do esforço coletivo de guerra que, a partir de 1941, permitiu a cooptação de inúmeros intelectuais pelo Estado britânico.

Logo após a declaração da Segunda Guerra Mundial, Gollancz passou a se dedicar às atividades extras ligadas ao clube, especialmente os comícios e demais eventos públicos por toda a Inglaterra, enquanto se ocupava do departamento de vendas do LBC. Para as outras atividades gerenciais do clube, Gollancz atribuiu grande responsabilidade a Norman Collins, que passou a gerir os aspectos editoriais do LBC. Nesse período, o aparato do LBC se torna um órgão de educação popular para servir à classe trabalhadora britânica.

Desde a metade da década de 1930, o perigo do fascismo já era um tema recorrente nas publicações do clube. Na verdade, desde o início da Guerra Civil Espanhola e os inúmeros trabalhos dedicados ao tema, a própria Left News dedicou duas edições especiais à guerra, além de inúmeros artigos tratando dos acontecimentos na Espanha. Contudo, com o início da guerra mundial, a ideia de educação das massas trabalhadoras se reforçou como um dos temas-chave do clube. Isso estava claro em vários dos editoriais assinados por Gollancz para a Left News a partir de 1939, em que a guerra mundial se apresentava não mais como uma ameaça, mas como uma realidade latente. No número 41, de setembro de 1939, essa afirmação era clara no editorial assinado conjuntamente pelos três editores do LBC, Gollancz, Strachey e Laski:

Temos dado, naturalmente, a máxima atenção à posição do Left Book Club na [Segunda] Guerra.

É necessário recordar que todo o propósito do Clube foi anunciado no cabeçalho de seu primeiro prospecto e repetido sem alteração em cada número atéao momento presente [...] O objetivo étriplo - a preservação da paz, a luta contra o fascismo e da luta por uma melhor ordem social e econômica: o método já está claro, ou seja, é educacional. ${ }^{40}$

Ao mesmo tempo em que se reconhecia a importância dos projetos educacionais para a classe trabalhadora, essa deveria ocorrer paralela à luta contra

40 "We have naturally given the most careful attention to the position of the Left Book Club in the War. It is necessary to recall the whole purpose of the Club was announced at the head of its first prospectus and repeated without alteration in every prospectus up to the present moment [... ] The aim is three-fold - the preservation of peace, the struggle against Fascism and the struggle for a better social and economic order: the method is giving of knowledge- namely, it is educational." GOLLANCZ; STRACHEY; LASKI. "The L.B.C. In a War time". Left News, n.41, set. 1939, p.1381. 
o fascismo. É interessante notar, no entanto, que nesse momento a palavra "revolução" pouco aparecia nos editoriais da Left News (diferente dos artigos assinados pelos diversos colaboradores que contribuíam com a revista). Em contraposição, a palavra "educação" parecia substituí-la no sentido de indicar um caminho para transformações políticas, econômicas e sociais profundas, talvez, com um sentido planejado de afastar as diretrizes centrais do LBC do jargão oficial do CPGB e do Comintern - ao que parece, ainda fruto das cicatrizes deixadas pelas controvérsias criadas pelo pacto de não agressão entre Hitler e Stalin, assinado em 1939. E esse caráter "independente" do LBC parecia ser necessário reafirmar também no mesmo editorial:

\begin{abstract}
Também é preciso lembrar duas coisas que têm sido repetidamente enfatizadas em comícios, discursos e publicações oferecidas pelo Clube. A primeira é que o Clube não tem uma política, que não seja o objetivo tríplice geral invocado no prospecto. Isto foi explicitamente declarado sob a forma de palavras por Gollancz no primeiro grande comício em Albert Hall. O segundo ponto que tem sido constantemente enfatizado é que o Left Book Club é e deve permanecer completamente independente de qualquer partido político. ${ }^{41}$
\end{abstract}

Gollancz sempre fez questão de afastar-se da militância oficial do CPGB ou mesmo do Labour Party, diferente de Strachey, que foi filiado aos trabalhistas antes e depois do Popular Front, e Laski, que integrava a linha de frente do partido. A manutenção de uma atuação "independente" de Gollancz e do LBC dentro do Popular Front e, depois, ao longo da Segunda Guerra Mundial, é afirmado pelo editor, por exemplo, em carta dirigida a Morley Kennerley.42 Quatro dias antes, Kennerley ${ }^{43}$ entrara em contato com Gollancz para tratar da organização do livro European Communism, e comentara um artigo recente de Franz Borkenau sobre suas memórias do Popular Front, em que fazia referência a Gollancz e sua militância em prol do CPGB. Em sua resposta, Gollancz diz a Kennerley que nunca fora filiado ou ligado de alguma maneira ao CPGB, mas que manteve estreitas ligações com membros do partido, pois atuava dentro das linhas do Popular Front, cuja ideia era justamente reunir um grupo amplo da esquerda na luta internacional contra o fascismo. Em sua resposta a Kennerley, Gollancz escreve o seguinte:

(...) "Romper com o partido" [Borkenau havia afirmado que Gollancz rompera com o CPGB após 1939] sugere que eu era um membro do partido. Em tempo algum eu fora membro do Partido Comunista, direta ou indiretamente, oficialmente ou não, secreta ou abertamente. $O$ Partido Comunista estava ativo, de 1936 a algum tempo em 1939, forçando políticas com que eu era (e ainda sou) retrospectivamente de grande acordo. Ele forçou, por exemplo, a ideia de uma associação da Grã-Bretanha, França e União Soviética para torná-lo claro para Hitler com antecedência de que eles estariam juntos caso ele atacasse. Isso me pareceu a forma mais esperançosa de prevenção da guerra, e eu

41 "It is also necessary to recall two things that have been repeatedly emphasized in rallies, speeches and the literature put out by the Club. The first is that the Club has no policy, other than the general three-fold aim put forward in the prospectus. This was explicitly stated, in the form of words, by Gollancz at the first great Albert Hall Rally. The second point which has been constantly emphasized is that the Left Book Club is and must remain completely independent of any political party." GOLLANCZ; STRACHEY; LASKI. "The L.B.C. In a War time". Left News, n.41, set. 1939, p.1381.

42 Carta datada de 18 de fevereiro de 1952. MSS.157/3/LB/2/3.i. Victor Gollancz paper, Modern Records Center, University of Warwick.

43 Carta datada de 14 de fevereiro. MSS.157/3/LB/2/1. Victor Gollancz paper, Modern Records Center, University of Warwick. 
ainda penso assim. O Partido Comunista era ativo no apoio aos republicanos espanhóis: na minha opinião, ele era totalmente certo em fazê-lo (quaisquer eram suas razões) e eu ainda penso assim. ${ }^{44}$

Em suas cartas privadas, Gollancz parecia querer deixar claro que sua concordância com as linhas gerais da política proposta pelo CPGB sobre várias questões latentes da época, não significou, no entanto, sua filiação ao partido. Como editor sênior do LBC, Gollancz pareceu forçar o clube a, também, não vincular-se oficialmente a nenhum dos partidos da esquerda britânica. No entanto, diante de sua posição quase gravitacional dentro Popular Front britânico, o LBC tornou-se suporte das atividades da esquerda e de onde os partidos de esquerda angariavam novos membros e difundiam seu programa e estratégias. Relação que parece ficar clara, em outro trecho da mesma carta de Gollancz a Kennerley:

O Left Book Club estava intimamente associado com o movimento da Frente Popular e, como os comunistas eram muito ativos na Frente Popular, eles estavam ativos no Left Book Club também. Mas é grotesco dizer que a qualquer momento eles tinham "controle" do mesmo, ou qualquer coisa como isto, ou que era um de seus instrumentos "propaganda”. O controle dos três editores - Harold Laski, John Strachey e eu - era absoluto, e minha própria influência foi, sem dúvida, a mais forte das três. Eu não sou o tipo de pessoa, como você provavelmente pode adivinhar, que pode ser "controlada" por ninguém. É pouco provável que o Sr. [Clement] Attlee teria publicado uma das "escolhas" do Left Book Club - "The Labour Party in Perspective" - se este fosse controlado pelos comunistas. Em duas ocasiões, na verdade, o Partido Comunista veementemente me solicitou não publicar pelo Left Book Club, dois livros que eles achavam ofensivo para eles; é claro que eu os publiquei. ${ }^{45}$

O dirigismo do CPGB parece ter sido então outro dos desafios enfrentados por Gollancz à frente do LBC. E muitos intelectuais sentiriam, ao longo de suas histórias pessoais como membros do partido, a mão pesada da ortodoxia sobre seus ombros. No campo da historiografia, por exemplo, Maurice Dobb (que participou de inúmeros seminários e Summer Schools organizados pelo LBC) e Christopher Hill são bons exemplos das dificuldades criadas pela ortodoxia do CPGB para a produção marxista que não seguisse os cânones interpretativos oficiais. O mesmo ocorrera com os expoentes do movimento SRS que publicaram pelo LBC. Foram os casos de J.B.S Haldane, que publicou dois de seus principais livros,

$44($...) "Broke with the party" suggests that I was a member of the party. I was at no time member of the Communist party, directly or indirectly, officially or unofficially, secretly or openly. The Communist party was active, from 1936 to some time in 1939, in pushing policies wich I was (and still retrospectively am) in strong agreement. It pushed, for instance, the idea of an association of Great Britain, France and the Soviet Union to make it clear to Hitler in advance that they would be together if he attacked. That seemed to me the most hopeful way of preventing war, and I still think so. Communist party as was active in supporting the Spanish Republicans: in my view, they were wholly right in doing so (whatever their reasons may have been) and I still think so. Gollancz to Kennerley, 18 de fevereiro de 1952, Modern Records Center, University of Warwick.

45 "The Left Book Club was closely associated with the Popular Front movement, and, as the Communists were very active in the Popular Front, they were active in the Left Book Club also. But it is grotesque to say that at any time they had "control" of it, or anything like it, or that it was one of their "propaganda" instruments. The control of the three selectors - Harold Laski, John Strachey and myself - was absolute, and my own influence was no doubt the strongest of the three. I am not the sort of person, as you can probably guess, to be "controlled" by anyone. It is hardly likely that Mr. Attlee would have written one of the "choices" for the Left Book Club - "The Labour Party in Perspective" - it had been controlled by the Communists. On two occasions, indeed, the Communist Party strongly requested to me not to publish, in the Left Book Club, two books which they thought offensive to them: of course I publish them". Gollancz to Kennerley, 18 de fevereiro de 1952, MSS.157/3/LB/2/3.i e MSS.157/3/LB/2/3.ii. 
A.R.P. (setembro de 1938) e How to be safe from air raids (novembro de 1938, baseado nas experiências das equipes médicas britânicas durante a Guerra Civil Espanhola) e Joseph Needham que, sob pseudônimo de "Henry Holorenshaw", publicou The Levellers and the English Revolution (março de 1939). ${ }^{46}$ Muitos dos autores publicados por Gollancz, mais tarde, seriam execrados pelo movimento comunista britânico por suas opiniões dissonantes das linhas oficiais stalinistas ou mesmo encontrariam dificuldades de publicação pelo próprio LBC, como vimos no caso de Orwell. ${ }^{47}$

Ao analisarmos os catálogos dos livros publicados pelo LBC, concluímos que pensar em qualquer sentido de uma unidade (no sentido ideológico) da linha editorial do clube seria incorrer em um erro interpretativo, mesmo que as falas de seus editores, especialmente de Gollancz, insistissem nessa linha por repetidas vezes, por exemplo, nos editoriais para a Left News. Pensar então no LBC como um campo mais amplo, de confronto de posições ideológicas diversas dentro da esquerda britânica, parece refletir melhor sua relação com a própria estrutura do Popular Front.

Vemos, com isso, que a própria função de guarda-chuva desempenhada pelo LBC, ao contrário do que sugeriam as diretrizes editoriais traçadas por Gollancz, Strachey e Laski, aglutina uma diversidade de posições ideológicas muito maior do que, de fato, os próprios editores do LBC estavam preparados para aceitar. E fora a partir dessa diversidade que as redes de comunicação costuradas pelo clube dariam vazão à formação de novas associações longe do núcleo duro, ligado, mesmo que informalmente, ao CPGB e ao Labour Party. O que, de fato, favoreceu, inclusive, os editores do LBC. O próprio Gollancz, por exemplo, contribuiu com alguns artigos para a revista Politics, ligada aos círculos trotskistas de Nova York, fundada e dirigida por Dwight Macdonald, em 1941, logo após seu rompimento com a célebre revista Partisan Review.

A coesão tênue proposta pelas Frentes Populares (e a necessidade de acomodar as rivalidades internas da esquerda), somada ao anticomunismo que perdurou mesmo durante os anos da Segunda Guerra Mundial, criou outro problema que agora já nos parece plausível: uma aura de autocensura em torno das atividades do LBC. Gollancz deixa isso claro, por exemplo, em resposta à carta de R. Wood, enviada em 4 de fevereiro de $1946 .{ }^{48}$ Nela, Gollancz afirmaria não saber como tratar de temas ligados à URSS, pois “[...] O problema é que eu não quero 'assustar' uma parcela grande dos membros, porque eu acredito que eles podem ser educados" [tradução livre, grifo meu]. Nessa carta, Gollancz respondia à sugestão de R. Wood pela publicação do livro The Betrayal of the Left (organizado por Gollancz, Strachey e Orwell) no formato de artigos, pela Left News. Outros dois pontos devem ser destacados nessa correspondência trocada entre Gollancz e Wood: 1) Gollancz comenta que a Left News tinha maior repercussão do que os livros publicados pelo LBC. Ou seja, os textos na revista, provavelmente, causavam maior impacto entre os associados

46 Informações disponíveis no catálogo da Left Book Club Collection, Sheffield University.

47 Além dos casos já citados de Orwell, estavam Frank Jellinek, que publica pelo Left Book Club dois livros: The Civil War in Spain (junho de 1938) e The Paris Commune of 1871 (fevereiro de 1937); Arthur Koestler, que publica ali também dois livros: The scum of the Earth (maio de 1941) e Spanish testament (dezembro de 1937); André Malraux, que publica Days of contempt (agosto de 1936); Stephen Spender, que publica, Foward from Liberalism (janeiro de 1937); etc. Esses são alguns nomes que seriam identificados mais tarde como "dissidentes" do movimento comunista britânico catálogo da Left Book Club Collection, Sheffield University. Disponível em: librarysupport.shef.ac.uk/leftbook.pdf.

48 Para a carta de R. Wood ver o documento MSS.157/3/LB/1/28 e para a reposta de Gollancz de 7 de fevereiro de 1946, ver MSS.157/3/LB/1/29, ambos no Victor Gollancz Papers, Modern Records Center, University of Warwick. 
do clube e, por isso, era necessário algum tipo de "cautela estratégica" para não "cindir" com "grande parcela dos membros" e, nas palavras de Gollancz, buscar sua "educação"; e 2) fica claro que Gollancz se autocensurava. Com isso, de certa forma, restringia as atividades do LBC, evitando publicar temas que levassem a um choque grande de opiniões com os comunistas. Essa autocensura, declarada já no contexto do pós-Segunda Guerra Mundial, pode ajudar, por exemplo, a explicar a relação de Gollancz com, por exemplo, George Orwell, e em sua recusa para publicar o Homage to Catolonia, em 1938, e do Animal Farm, em 1945.

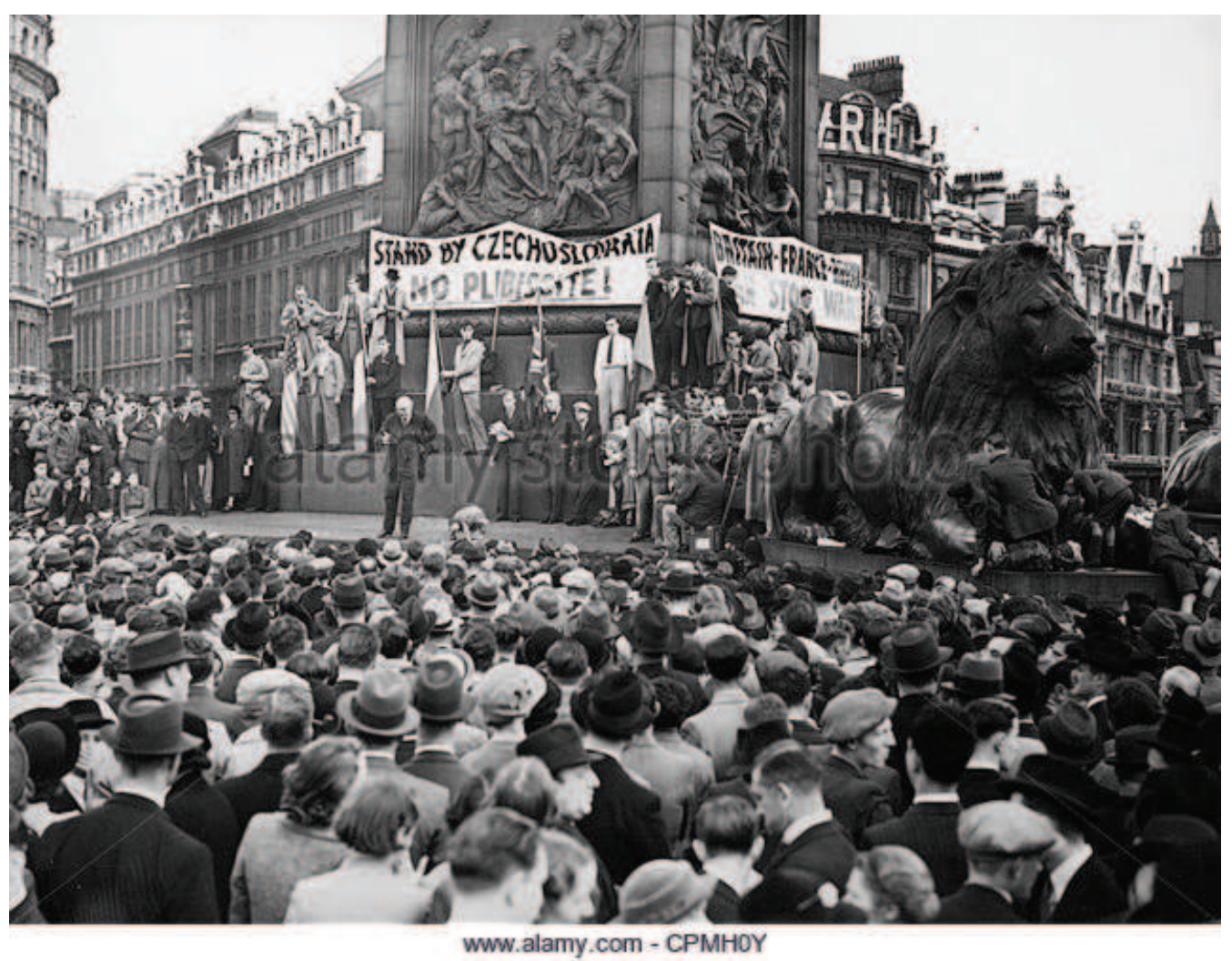

Victor Gollancz discursando em manifestação na Trafalgar Square, no centro de Londres, em 18 de setembro de 1938, durante a "Crise dos Sudetos". Direitos da imagem pertencentes ao acervo Alamy.com.

\section{Conclusão}

Como vimos, a história pessoal de Victor Gollancz está atrelada diretamente a sua vida profissional tanto à frente de sua editora, a Victor Gollancz Ltd., quanto ao Left Book Club. De fato, seria um erro negligenciar o alcance dessas experiências, especialmente em um momento de crise econômica e social de uma sociedade regida por uma economia de guerra. O número de 57 mil associados atingidos em 1938, dava ao LBC não apenas a condição do grupo mais popular e de maior alcance entre os projetos culturais da esquerda britânica, como nos dá a clara noção de como as pessoas estavam ávidas por uma saída renovada para as agruras de seu tempo.

A comprovação da receptividade do $L B C$ e dos alcances de sua atuação pode ser confirmada na mudança da opinião pública britânica que, por fim, levaria à vitória histórica do Labour Party nas eleições gerais de 1945.49 O encerramento das

49 O papel do LBC na campanha do Labour Party para as eleições gerais que levariam a vitória do partido em 1945, é afirmado, entre outras fontes, na carta-resposta da secretaria de Victor Gollancz a Richard Rose 
atividades do clube, em finais 1947, foi por vezes atribuído à vitória do trabalhista e ao esgotamento do projeto proposto com a fundação do LBC. Mesmo antes de 1945, a influência do clube já podia ser notada através dos livros que mais tiveram impacto na opinião pública britânica na primeira metade da década de 1940. Entre eles, Walls have Mouths, de Wilfred McCartney, que expunha a condição das prisões britânicas e teve papel decisivo na reforma penitenciária do país, quando foi permitido o fumo por detentos, publicado pelo LBC em 1937; The Labour Party in Perspective, de Clement R. Attlee, que viria a se tornar primeiro-ministro britânico logo após o fim da Segunda Guerra Mundial, também publicado pelo LBC em 1937; e Fallen Bastions, de G.E.R. Gedye, sobre os estupros na Checoslováquia durante a Segunda Guerra Mundial, publicado pelo LBC em 1939.50

O próprio Labour Party entendeu que a atuação do LBC como difusor e organizador da esquerda não comunista britânica foi fundamental para sua subida ao poder logo após o fim da Segunda Guerra Mundial. Tanto que, por diversas vezes, tentou estreitar oficialmente seus laços com o LBC, como em cartas endereçadas a Victor Gollancz, sugerindo a criação de um vínculo que permitisse a publicação de obras selecionadas por um comitê do partido sob o selo do clube. Os arquivos privados de Victor Gollancz, sob os cuidados da Modern Records Center, da University of Warwick, guardam duas cartas de dirigentes do Labour Party dirigidas a Gollancz, solicitando um estreitamento de relações com o LBC. Nos mesmos arquivos há um outro documento, intitulado "Note on the Left Book Club" 51 que parece ter sido produzido também pelo Labour Party (sem assinatura), descrevendo a posição estratégica do LBC na difusão de material de propaganda e livros escolhidos pelo Labour Party. A nota aponta ainda que Gollancz não abriria mão do controle sobre as escolhas dos livros a serem publicados; nomearia os membros do conselho editorial; e, caso a parceria fosse fechada, indicaria que os livros selecionados pelo partido poderiam ser acompanhados de uma tarja "labour party choice" ou algo similar. Já a ligação entre o partido e o LBC se daria por meio de Harold Laski e de um comitê definido pelo partido para as escolhas.

É inegável então o alcance que o projeto proposto pelo Left Book Club assumiu em seus anos de atuação, entre sua fundação, em finais de 1935 e seu fechamento, em 1947. E ele, não há como negar, carrega consigo a história pessoal de seu principal mentor e editor, Victor Gollancz. O que reafirma sua condição de personagem-chave de um dos momentos mais importantes da história da esquerda britânica.

Recebido em 27/07/2016

Aprovado em 04/11/2016

(MSS.157/3/LB/2/18) de 2 de janeiro de 1958 para sua tese de doutorado in Oxford sobre a influencia socialista na política externa do Labour Party. Ambos os documentos pertencentes ao Modern Records Center, University of Warwick.

50 Todas as informações estão na resposta da secretária de Gollancz (MSS.157/3/LB/2/6.i), de 21 de novembro de 1956, à carta de Roy Hill (MSS.157/3/LB/2/5), de 20 de novembro de 1956, em que Hill solicitava detalhes sobre a organização do LBC para um livro sobre o período.

51 MSS.157/3/LB/1/68. Victor Gollancz papers, Modern Records Center, University of Warwick. 